\title{
PENYELESAIAN SENGKETA PERBANKAN PASCA KELUARNYA UNDANG-UNDANG NOMOR 21 TAHUN 2011 TENTANG OTORITAS JASA KEUANGAN
}

\author{
Muhamad Kholid \\ Fakultas Syari'ah dan Hukum UIN Sunan Gunung Djati Bandung \\ Jl. A. H. Nasution Nomor 105 Bandung \\ Email: muhamadcholied@yahoo.co.id
}

\begin{abstract}
Abstrak
Otoritas Jasa Keuangan merupakan lembaga independen dan bebas dari campur tangan pihak lain, mempunyai fungsi, tugas, dan wewenang pengaturan, pengawasan, pemeriksaan, dan penyidikan termasuk memfasilitasi mediasi pada lembaga keuangan perbankan dan non perbankan. Sebelumnya BI merupakan lembaga yang menjadi fasilitator untuk penyelesaian sengketa-sengketa perbankan yang tidak selesai pada tahapan Unit Pengaduan Internal Bank sebagaimana diamanatkan PBI Nomor: 8/5/PBI/2006 tentang Mediasi Perbankan dan PBI Nomor: 10/1/PBI/2008 tentang Perubahan Atas Peraturan Bank Indonesia Nomor: 8/5/PBI/2006 tentang Mediasi Perbankan tetapi semenjak lahirnya Undang-undang Nomor 21 Tahun 2011 tentang Otoritas Jasa Keuangan yang isinya memberikan kewenangan untuk menjadi regulator dan supervisor pada lembaga keuangan perbankan dan non perbankan di Indonesia agar keseluruhan kegiatan di dalam sektor jasa keuangan terselenggara secara teratur, adil, transparan, dan akuntabel; mewujudkan sistem keuangan yang tumbuh secara berkelanjutan dan stabil; dan melindungi kepentingan konsumen dan masyarakat. Tulisan ini akan memberikan deskripsi tentang penyelesaian sengketa perbankan melalui Otoritas Jasa Keuangan pasca keluarnya UndangUndang Nomor 21 Tahun 2011.
\end{abstract}

\section{Kata Kunci:}

Mediasi, Otoritas Jasa Keuangan, Sengketa Perbankan,

\section{A. Pendahuluan}

Lembaga Keuangan merupakan perusahaan yang bergerak di bidang keuangan, menghimpun dana, menyalurkan dana atau keduanya atau dalam kata lain sebagai lembaga perantara antara pihak yang 
kelebihan dana (surplus of funds) dengan pihak yang kekurangan dana (lack of funds). Diantara lembaga yang bergerak di bidang keuangan adalah perbankan. Perbankan memiliki peranan yang sangat penting (signifikan) karena bertujuan untuk menunjang pelaksanaan pembangunan nasional dalam rangka meningkatkan pemerataan, pertumbuhan ekonomi, dan stabilitas nasional kearah peningkatan kesejahteraan rakyat banyak. Dengan kata lain, perbankan merupakan "jantungnya" suatu negara.

Perkembangan perbankan di Indonesia mengiringi sejarah pembentukan dan pertumbuhan negara ini. Bahkan sebelum negara ini terbentuk, perbankan sudah lebih dahulu ada di Indonesia seperti berdirinya N.V. De Javasche Bank pada abad 19, N.V. Escompto Bank pada tahun 1857 dan Bank Priyayi (De Poerwokertosche Hulpen Spaarbank de Inlandsche Hoofden) pada tahun 1895. Berdasarkan data yang dirilis Direktori Perbankan Indonesia tahun 2013 menerangkan jumlah lembaga perbankan konvensional di Indonesia adalah 4 Bank Pesero, 35 Bank Swasta Nasional Devisa, 30 Bank Swasta Nasional Non Devisa, 26 Bank Pembangunan Daerah, 15 Bank Campuran, 10 Bank Asing, dan terdapat 31 Layanan Syariah (office Channeling). ${ }^{1}$

Seiring dengan reformasi di bidang hukum perbankan, yaitu lahirnya Undang-undang Nomor 7 Tahun 1992 tentang Perbankan. Pada Pasal 1 ayat (12) tentang definisi kredit yaitu sebagai berikut:

"persetujuan atau kesepakatan pinjam-meminjam antara bank dengan pihak lain yang mewajibkan pihak peminjam untuk melunasi hutangnya setelah jangka waktu tertentu dengan jumlah bunga, imbalan atau pembagian hasil keuntungan."

Aturan di atas merupakan awal pintu gerbang digunakannya prinsip-prinsip syariah dalam kegiatan usaha perbankan di Indonesia yaitu menggunakan sistem pembagian hasil keuntungan. Dengan demikian, perbankan Indonesia menggunakan 2 (dua) sistem (dual banking system) yaitu Perbankan Konvensional dengan konsep bungan dan Perbankan Syariah dengan konsep bagi hasil.

Adanya perubahan atas Undang-undang Nomor 7 Tahun 1992 tentang Perbankan yaitu lahirnya Undang-undang Nomor 10 Tahun 1998 (selanjutnya disebut Undang-Undang tentang Perbankan), memberikan landasan yuridis normatif yang lebih jelas tentang kegiatan usaha perbankan dengan menggunakan Prinsip-prinsip Syariah. Hal ini

${ }^{1}$ www.bi.go.id 
dapat dilihat dari adanya definisi Bank Umum, Bank Perkreditan Rakyat (BPR), Pembiayaan Berdasarkan Prinsip Syariah, Prinsip Syariah dan Agunan.

Undang-Undang Perbankan di atas diperkuat dengan lahirnya Undang-undang Nomor 21 Tahun 2008 tentang Perbankan Syariah (selanjutnya disebut Undang-Undang Perbankan Syariah) pada tanggal 16 Juli 2008, yang menjadi peraturan khusus (lex specialis) Perbankan Syariah di Indonesia. Perkembangan perbankan syariah di Indonesia diawali dengan berdirinya Bank Perkreditan Rakyat Syariah yaitu Bank Perkreditan Rakyat Daerah Mardhatillah (BPRDM), dan Bank Perkreditan Rakyat Berkah Amal Sejahtera (BPRBAS), yang didirikan pada tanggal 15 Juli 1991 di Bandung, Jawa Barat. Kemudian setelah lahirnya Undang-Undang Perbankan maka mulai bermunculan Bank Syariah dan Bank Konvensional yang usaha-usahanya menggunakan Prinsip-prinsip Syariah (Unit Usaha Syariah). Pendirian Bank Syariah dan Unit Usaha Syariah (UUS) untuk mengantisipasi kesenjangan perekonomian umat Islam di Indonesia. Oleh karena itu, para cendikiawan muslim, para ulama, dan masyarakat muslim terus mendorong Pemerintah untuk memfasilitasi umat Islam agar memiliki akses terhadap dunia perbankan dalam rangka meningkatkan usahanya melalui berbagai kredit tanpa ada unsur riba. Undang-Undang Perbankan telah mengakomodasi kepentingan bisnis umat Islam melalui perbankan, sehingga diharapkan dapat meningkatkan partisipasi umat Islam dalam penyertaan dana masyarakat dalam bentuk tabungan atau mendapat berbagai kredit perbankan. Keberadaan perbankan syariah di Indonesia mengalami perkembangan yang sangat pesat setidaknya terdapat 11 Bank Umum Syariah (BUS), 158 Bank Pembiayaan Rakyat Syariah (BPRS), dan 31 Unit Usaha Syariah. ${ }^{2}$

Keberadaan dan perkembangan perbankan di Indonesia selain berdampak positif atas pertumbuhan ekonomi nasional karena semakin banyaknya akses masyarakat pada bidang perbankan. juga berdampak negatif, diantaranya adalah banyaknya sengketa-sengketa di bidang perbankan. Pasal 10 Undang-undang Nomor 48 Tahun 2009 tentang Kekuasaan Kehakiman (selanjutnya disebut Undang-Undang Kekuasaan Kehakiman), berbunyi sebagai berikut: 
Pengadilan dilarang menolak untuk memeriksa, mengadili, dan memutus suatu perkara yang diajukan dengan dalih bahwa hukum tidak ada atau kurang jelas, melainkan wajib untuk memeriksa dan mengadilinya.(1) Ketentuan sebagaimana dimaksud pada ayat (1) tidak menutup usaha penyelesaian perkara perdata secara perdamaian.(2)

Berdasarkan pasal di atas, terdapat 2 (dua) macam cara penyelesaian sengketa yaitu melalui lembaga pengadilan (litigasi) yakni Pengadilan Negeri (PN) atau Pengadilan Agama (PA) dan lembaga di luar pengadilan (non litigasi) yakni melalui cara konsultasi, negosiasi, mediasi, konsiliasi, atau penilaian ahli dan arbitrase.

Penyelesaian sengketa perbankan di Indonesia dilakukan dengan melalui beberapa tahapan yaitu pertama, melalui lembaga Unit Pengaduan Internal Bank sebagaimana diatur dalam Peraturan Bank Indonesia Nomor: 7/7/PBI/2005 tentang Penyelesaian Pengaduan Nasabah. Apabila nasabah tidak puas dengan putusan dari Unit Pengaduan Internal Bank maka dapat mengajukan proses hukum selanjutnya yaitu pada tahapan kedua, yakni kelembagaan mediasi perbankan sebagaimana diatur dalam Peraturan Bank Indonesia No: 8/5/PBI/2006 Tentang Mediasi Perbankan.

Pertimbangan hukum keluarnya PBI No.8 Tahun 2006 adalah sebagai berikut:

1. Bahwa penyelesaian pengaduan nasabah oleh bank tidak selalu dapat memuaskan nasabah dan berpotensi menimbulkan sengketa di bidang perbankan antara nasabah dengan bank;

2. Bahwa penyelesaian sengketa di bidang perbankan yang berlarutlarut dapat merugikan nasabah dan meningkatkan risiko reputasi bagi bank; dan

3. Bahwa penyelesaian sengketa di bidang perbankan antara nasabah dengan bank dapat dilakukan secara sederhana, murah, dan cepat melalui cara mediasi.

Pasal 3 ayat (1) PBI No.8 Tahun 2006 mengatur bahwa mediasi di bidang perbankan dilakukan oleh lembaga mediasi perbankan independen yang pembentukannya diamanatkan kepada asosiasi perbankan. Amanat pembentukan lembaga mediasi perbankan independen berdasarkan Pasal 3 ayat (2) selambatnya-lambatnya dibentuk tanggal 31 Desember 2007 tetapi sampai waktu yang ditentukan lembaga mediasi perbankan independen tersebut belum kunjung terbentuk 
maka keluarnya Peraturan Bank Indonesia Nomor: 10/1/PBI/2008 Tentang Perubahan Atas Peraturan Bank Indonesia No: 8/5/PBI/2006 tentang Mediasi Perbankan (selanjutnya disebut PBI No.10 Tahun 2008).

Pasal 3 ayat (1) (selanjutnya disebut PBI No.8 Tahun 2006) memperkuat bahwa lembaga mediasi perbankan independen dibentuk oleh asosiasi perbankan yang dalam pelaksanaan tugasnya berkoordinasi dengan Bank Indonesia. Hal ini dikarenakan sepanjang lembaga mediasi perbankan syariah belum terbentuk maka fungsi mediasi perbankan dilaksanakan oleh Bank Indonesia.

Pasal 8 Undang-Undang Nomor 23 Tahun 1999 tentang Bank Indonesia (selanjutnya disebut dengan Undang-Undang Nomor 23 Tahun 1999) mengingatkan bahwa tugas pokok Bank Indonesia adalah sebagai berikut:

1. Menetapkan dan melaksanakan kebijakan moneter;

2. Mengatur dan menjaga kelancaran sistem pembayaran; dan

3. Mengatur dan mengawasi Bank.

Sedangkan tujuan pelaksanaan tugas pokok bagi Bank Indonesia adalah mencapai dan memelihara kestabilan nilai rupiah. ${ }^{3}$ Dengan demikian, penyelesaian perkara melalui mediasi perbankan yang difasilitasi oleh Bank Indonesia menjadi bersifat sementara sehingga diharapkan tidak mengganggu terhadap tugas pokok dan tujuan pembentukan Bank Indonesia. Data dari Bank Indonesia, terdapat 679.035 pengaduan pada tahun 2010 dan meningkat menjadi 853.892 pengaduan pada tahun 2011 dan terus meningkat menjadi 884.454 pada tahun 2012. Departemen Investigasi dan Mediasi Perbankan Bank Indonesia mencatat sudah terdapat 361 permohonan mediasi terhadap kasus sengketa bank dan nasabah sepanjang bulan januari-september 2013.4

Lahirnya Undang-undang Nomor 21 Tahun 2011 tentang Otoritas Jasa Keuangan (selanjutnya disebut Undang-Undang OJK) yang memberikan kewenangan pengaturan dan pengawasan lembaga keuangan perbankan dan bukan perbankan beralih dari Bank Indonesia ke 0JK. Hal ini dapat dilihat pada Pasal 6 Undang-Undang OJK di bawah ini:

\footnotetext{
3 Pasal 7 Undang-Undang Nomor 23 Tahun 1999 tentang Bank Indonesia.

4 Dinda Wulandari, BI: Pengaduan Nasabah Melonjak dalam 3 Tahun Terakhir, dalam http://bisnis.com, diunduh Tanggal 28 Maret 2015.
} 
Otoritas Jasa Keuangan melaksanakan tugas pengaturan dan pengawasan terhadap:

1. Kegiatan jasa keuangan di sektor Perbankan;

2. Kegiatan jasa keuangan di sektor Pasar Modal; dan

3. Kegiatan jasa keuangan di sektor Perasuransian, Dana Pensiun, Lembaga Pembiayaan, dan Lembaga Jasa Keuangan Lainnya.

Pasal 29 Undang-Undang OJK mengatur terkait pelayanan pengaduan konsumen yang meliputi:

1. Menyiapkan perangkat yang memadai untuk pelayanan pengaduan Konsumen yang dirugikan oleh pelaku di Lembaga Jasa Keuangan;

2. Membuat mekanisme pengaduan Konsumen yang dirugikan oleh pelaku di Lembaga Jasa Keuangan; dan

3. Memfasilitasi penyelesaian pengaduan Konsumen yang dirugikan oleh pelaku di Lembaga Jasa Keuangan sesuai dengan peraturan perundang-undangan di sektor jasa keuangan.

Dengan demikian, sejak bulan Januari 2014 fungsi, tugas, wewenang pengaturan dan pengawasan termasuk kegiatan mediasi perbankan dialihkan dari BI ke OJK. Berdasarkan uraian di atas, penulis bermaksud melakukan peneletian lebih lanjut mengenai penyelesaian sengketa perbankan pasca keluarnya Undang-Undang Nomor 21 Tahun 2011 Tentang Otoritas Jasa Keuangan

\section{B. Prosedur Penyelesaian Sengketa Perbankan}

Secara umum, penyelesaian sengketa dapat melalui lembaga peradilan (litigasi) dan lembaga di luar peradilan (non litigasi). Untuk sengketa perbankan yang melalui lembaga peradilan diselesaikan melalui Pengadilan Negeri dan Pengadilan Agama sedangkan yang melalui lembaga di luar peradilan melalui konsultasi, negosiasi, mediasi, konsiliasi, penilaian ahli dan arbitrase. Mengingat banyaknya transaksi yang melalui bank maka tidak mungkin dapat terhindar terjadinya sengketa antara para pihak yang terlibat. Apabila sengketa perbankan tersebut dibiarkan atau lambat dalam penyelesaian maka akan berdampak negatif terhadap perkembangan dunia perbankan itu sendiri, apabila perbankan terganggu maka pembangunan ekonomi menjadi tidak stabil, produktifitas menurun, dan dunia bisnis akan mengalami kemunduran.

Pada umumnya kalangan dunia usaha dan dagang termasuk perbankan lebih menyukai penyelesaian di luar pengadilan seperti melalui Alternatif Penyelesaian Sengketa (APS) atau lembaga arbitrase 
dalam menyelesaikan sengketanya dibanding pengadilan dengan alasan sebagai berikut:

1. kerahasiaan sengketa para pihak terjaga;

2. putusan mengikat (legal and binding) dan bersifat win win solution; dan

3. para pihak dapat menentukan arbiter, pilihan hukum, proses dan tempat penyelenggaraan serta prosedural.

Tahapan penyelesaian perkara perbankan melalui lembaga di luar peradilan dilakukan dengan mengajukan penyelesaian perkaranya ke Unit Pengaduan Internal Bank. Adapun mekanisme pengaduan nasabah sesuai dengan PBI No.7 Tahun 2005 tentang Penyelesaian Pengaduan Masalah diserahkan kepada Unit Pengaduan Internal Bank sehingga bank wajib menetapkan kebijakan dan memiliki prosedur tertulis yang meliputi:

1. Penerimaan Pengaduan

Pengaduan dapat dilakukan secara lisan/tertulis pada setiap Kantor Bank.

2. Penanganan dan Penyelesaian Pengaduan

Pengaduan paling lambat 20 hari kerja setelah pengaduan dan dapat diperpanjang 20 hari.

3. Pemantauan Penanganan dan Penyelesaian Pengaduan

Bank wajib menyampaikan laporan penanganan dan penyelesaian Pengaduan secara triwulan kepada BI.

Apabila pihak nasabah tidak mendapatkan kepuasan atas hasil penyelesaian pengaduan dari Unit Pengaduan Internal Bank maka dapat mengajukan aduannya ke lembaga mediasi perbankan. Mediasi perbankan adalah lembaga penyelesaian sengketa yang melibatkan mediator untuk membantu para pihak yang bersengketa guna mencapai penyelesaian dalam bentuk kesepakatan sukarela terhadap sebagian ataupun seluruh permasalahan yang disengketakan. Syarat-syarat perkara dapat diajukan ke lembaga mediasi perbankan adalah:

1. Diajukan secara tertulis disertai dokumen pendukung yang memadai;

2. Pernah diajukan penyelesaiannya melalui internal bank;

3. Sengketa yang ajukan tidak sedang dalam proses atau belum pernah diputus oleh lambaga arbitrase atau peradlan, atau belum terdapat kesepakatan; 
4. Sengketa yang diajukan belum perbah diproses dalam medasi perbankan yang difasilitasi BI;

5. Pengajuan penyelesaian sengketa tidak melebihi 60 (enam puluh) hari kerja sejak tanggal surat hasil penyelesian pengaduan yang disampaikan bank kepada nasabah;

6. Nilai tuntutan finansial yang diajukan paling banyak sebesar Rp500.000.000 (lima ratus juta) untuk setiap kasus sengketa; dan

7. Tidak mengajukan tuntutan finansial yang diakibatkan kerugian immaterial.

Proses pemeriksaan sampai dengan penandatangan Akta Kesepakatan dilakukan dalam jangka waktu paling lama 30 (tiga puluh) hari kerja sejak Nasabah atau Perwakilan Nasabah dan Bank menandatangani Perjanjian Mediasi (agreement to mediate) dan dapat diperpanjang sampai dengan 30 (tiga puluh) hari kerja berikutnya berdasarkan kesepakatan Nasabah atau perwakilan Nasabah dengan Bank. Hasil kesepakatan antara Nasabah atau perwakilan Nasabah dengan Bank dituangkan dalam Akta Kesepakatan yang ditandatangani oleh para pihak.Pasal 3 PBI No. 8 Tahun 2006 tentang Mediasi Perbankan mengatur bahwa mediasi di bidang perbankan dilakukan oleh Lembaga Mediasi Perbankan Independen yang dibentuk asosiasi perbankan. Pada pelaksanaan tugasnya, Lembaga Mediasi Perbankan Independen melakukan koordinasi dengan Bank Indonesia dan sepanjang Lembaga Mediasi Perbankan Independen belum dibentuk maka fungsi Mediasi perbankan dilaksanakan oleh Bank Indonesia.

Bank Indonesia pada tahun 2012 telah menerima 521 perkara, rinciannya dapat dilihat dari tabel di bawah ini:

Tabel 1.

Jumlah Perkara yang Masuk ke BI

\begin{tabular}{|l|c|c|c|}
\hline \multirow{2}{*}{ Jenis Produk } & \multicolumn{3}{c|}{ Jumlah Sengketa } \\
\cline { 2 - 4 } & $\mathbf{2 0 1 0}$ & $\mathbf{2 0 0 1}$ & $\mathbf{2 0 1 2}$ \\
\hline Penghimpunan Dana & 35 & 47 & 59 \\
\hline Penyaluran Dana & 86 & 246 & 280 \\
\hline Sistem Pembayaran & 149 & 206 & 165 \\
\hline Produk kerjasama & 2 & 4 & 0 \\
\hline Produk Lainnya & 3 & 4 & 6 \\
\hline Diluar Permasalahan Produk Perbankan & 3 & 3 & 11 \\
\hline Total & $\mathbf{2 7 8}$ & $\mathbf{5 1 0}$ & $\mathbf{5 2 1}$ \\
\hline
\end{tabular}


Berdasarkan tabel di atas yang ditangani Bank Indonesia adalah sengketa keperdataan yang timbul dari transaksi keuangan adalah sebagai berikut:

1. Penghimpunan dana, meliputi giro, tabungan, deposito, antar bank, dan lain-lain;

2. Penyaluran dana, meliputi kredit, pembiayaan antar bank, dan lainlain;

3. Sistem pembayaran, meliputi ATM, kartu debit, kartu kredit, traveler chaque, kliring, RTGS, banking remittance, dan lain-lain;

4. Produk kerjasama, meliputi bancassurance, reksadana, dan lainlain;

5. Produk lainnya, meliputi bank garansi, trade finance, derivative wealth management, safe deposit box, dan lain-lain; dan

6. Di luar permasalahan produk pebankan.

Sengketa yang paling banyak adalah mengenai sistem pembayaran yaitu terkait ATM, kartu debit dan kartu kredit. Sebagaimana tabel di atas, pada tahun 2012 kelompok produk penyaluran dana merupakan kelompok yang paling banyak disampaikan permasalahannya kepada Bank Indonesia yaitu sebanyak 280 sengketa, 171 sengketa disampaikan oleh beberapa Lembaga Perlindungan Konsumen Swadaya Masyarakat, pada umumnya terkait dengan pembayaran denda/bunga, tidak diberikanya salinan kredit, dan keberatan atas cara penagihan/penyelesaian kredit yang dilakukan oleh Bank.

Bank Indonesia hingga triwulan I tahun 2012 telah menerima 148 kasus sengketa perbankan. Terdapat 25 perkara melalui layanan mediasi, sedangkan sisanya gugur dalam proses klarifikasi dan tidak masuk kriteria mediasi BI. Departemen Investigasi dan Mediasi Perbankan Bank Indonesia mencatat sudah terdapat 361 permohonan mediasi terhadap kasus sengketa bank dan nasabah sepanjang bulan januari-september 2013. Pada kurun waktu 2013, sengketa yang telah selesai ditangani pada pra mediasi sejumlah 37 pengaduan, dimana 23 pengaduan telah diselesaikan oleh bank dan 14 kasus lainnya selesai hanya melalui penyampaian edukasi oleh Bank Indonesia. Sementara itu, pengaduan yang berlanjut ke proses mediasi oleh Bank Indonesia berjumlah 27 pengaduan dengan 17 proses mediasi telah mencapai kesepakatan, sementara 10 proses mediasi lainnya tidak berhasil mencapai kesepakatan. 
Sejak lahirnya Undang-Undang $0 \mathrm{JK}$, tugas pengaturan dan pengawasan perbankan beralih dari Bank Indonesia ke 0JK. Pasal 6 Undang-Undang OJK di bawah ini: OJK melaksanakan tugas pengaturan dan pengawasan terhadap:

1. Kegiatan jasa keuangan di sektor Perbankan;

2. Kegiatan jasa keuangan di sektor Pasar Modal; dan

3. Kegiatan jasa keuangan di sektor Perasuransian, Dana Pensiun, Lembaga Pembiayaan, dan Lembaga Jasa Keuangan Lainnya.

Pasal 29 Undang-Undang OJK mengatur terkait pelayanan pengaduan Konsumen yang meliputi:

1. Menyiapkan perangkat yang memadai untuk pelayanan pengaduan Konsumen yang dirugikan oleh pelaku di Lembaga Jasa Keuangan;

2. Membuat mekanisme pengaduan Konsumen yang dirugikan oleh pelaku di Lembaga Jasa Keuangan; dan

3. Memfasilitasi penyelesaian pengaduan Konsumen yang dirugikan oleh pelaku di Lembaga Jasa Keuangan sesuai dengan peraturan perundang-undangan di sektor jasa keuangan.

Dengan demikian, sejak Januari 2014 fungsi, tugas dan wewenang pengaturan dan pengawasan kegiatan mediasi perbankan dialihkan ke OJK. Untuk keperluan itu, OJK sudah menerbitkan sejumlah peraturan dan surat edaran, namun tidak secara tegas mencabut Peraturan Bank Indonesia yang mengatur masalah serupa sebelumnya.

1. Peraturan OJK No: 1/POJK.07/2013 tentang Perlindungan Konsumen Sektor Jasa Keuangan;

2. Peraturan OJK No. 1/POJK.07/2014 tentang Lembaga Alternatif Penyelesaian Sengketa; dan

3. Surat Edaran OJK No. 2/SEOJK.07/2014 tanggal 14 Februari 2014 tentang Pelayanan dan Penyelesaian Pengaduan Konsumen Pada Pelaku Usaha Jasa Keuangan.

Walaupun demikian, Peraturan OJK tidak mencabut keberlakuan Peraturan BI selama ketentuan-ketentuan dalam Peraturan BI tidak bertentangan dengan Peraturan OJK. Dengan demikian, berdasarkan peraturan-peraturan yang berlaku proses penyelesaian sengketa perbankan dapat dibagi menjadi 2 (dua) tahapan yaitu:

\section{Tahapan Penyelesaian Pengaduan Konsumen Pada Bank}

POJK No.1 Tahun 2013 mewajibkan setiap Bank untuk memiliki unit yang dibentuk secara khusus di setiap kantor Bank untuk mena- 
ngani dan menyelesaikan pengaduan yang diajukan oleh Konsumen tanpa dipungut bayaran. Pengaduan harus didasari atas adanya kerugian/potensi kerugian finansial pada Konsumen karena kesalahan atau kelalaian Bank. Berdasarkan PBI No.7 Tahun 2005 pengaduan tersebut dapat dilakukan baik secara tertulis maupun secara lisan, pada setiap kantor Bank terlepas dari apakah kantor Bank tersebut merupakan kantor Bank tempat Konsumen membuka rekening dan/atau melakukan transaksi keuangan. Atas pengaduan yang dilakukan secara lisan, Bank wajib menyelesaikannya dalam jangka waktu dua hari kerja terhitung sejak tanggal pencatatan pengaduan. Apabila diperkirakan memerlukan waktu lebih lama, maka petugas unit penanganan dan penyelesaian pengaduan pada kantor Bank pengaduan lisan tersebut disampaikan meminta konsumen untuk mengajukan pengaduan secara tertulis.

Setelah menerima pengaduan tertulis dari Konsumen, Bank wajib menyelesaikan pengaduan terkait paling lambat 20 hari kerja sejak tanggal penerimaan pengaduan tertulis oleh Bank, dan dapat diperpanjang sampai dengan paling lama 20 hari kerja lagi dalam kondisi tertentu. Kondisi tertentu tersebut seperti:

a. Pengaduan tertulis disampaikan pada kantor Bank yang berbeda dengan kantor Bank tempat terjadinya permasalahan yang diadukan sehingga terdapat kendala komunikasi di antara kedua kantor Bank tersebut;

b. Transaksi keuangan yang diadukan Konsumen memerlukan penelitian khusus terhadap dokumen-dokumen Bank; atau

c. Terdapat hal-hal lain di luar kendali Bank, e.g keterlibatan pihak ketiga dalam transaksi keuangan yang dilakukan oleh Konsumen. Setiap perpanjangan wajib diberitahukan kepada Konsumen yang bersangkutan.

Penyelesaian pengaduan Konsumen sesuai dengan SE OJK No.2 Tahun 2014 dapat berupa pernyataan maaf atau ganti rugi kepada Konsumen. Ganti rugi diberikan untuk kerugian yang bersifat material, dengan ketentuan, diantaranya:

a. Konsumen telah memenuhi kewajibannya;

b. Terdapat ketidaksesuaian antara produk dan/ atau layanan Bank yang diterima dengan yang diperjanjikan;

c. Pengaduan diajukan paling lama 30 hari sejak diketahuinya produk dan/ atau layanan yang tidak sesuai dengan perjanjian; dan 
d. Kerugian berdampak langsung pada Konsumen. Ganti rugi yang ditetapkan oleh OJK maksimum sebesar nilai kerugian Konsumen.

\section{Tahapan Penyelesaian Sengketa Melalui OJK}

Apabila pengaduan Konsumen tidak dapat diselesaikan oleh Bank, maka Konsumen dapat mengajukan penyelesaian sengketa melalui pengadilan atau lembaga alternatif penyelesaian sengketa di sektor perbankan. Berdasarkan POJK No.1 Tahun 2014, lembaga alternatif penyelesaian sengketa di sektor perbankan dibentuk oleh bank-bank yang dikoordinasi oleh asosiasi perbankan, yang berwenang untuk memeriksa sengketa dan menyelesaikannya melalui mediasi, ajudikasi atau arbitrase. Apabila belum terbentuk lembaga yang bersangkutan, Konsumen dapat mengajukan permohonan fasilitas penyelesaian sengketa secara tertulis kepada OJK ditujukan kepada Anggota Dewan Komisioner OJK, Bidang Edukasi dan Perlindungan Konsumen, Direktorat Pelayanan Konsumen OJK, Gedung Radius Prawiro Lantai 2, Komplek Perkantoran Bank Indonesia, Jalan M.H. Thamrin No. 2, Jakarta Pusat 10350.

Adapun prosedur penyelesaian sengketa melalui OJK, OJK menunjuk fasilitator yang merupakan petugas OJK di bidang Edukasi dan Perlindungan Konsumen, Direktorat Pelayanan Konsumen OJK. Setelah itu Konsumen dan Bank wajib menandatangani perjanjian fasilitasi yang pada pokoknya menyatakan Konsumen dan Bank telah sepakat untuk memilih penyelesaian sengketa difasilitasi oleh OJK dan akan tunduk dan patuh pada aturan fasilitasi yang ditetapkan oleh OJK. Proses pelaksanaan fasilitasi oleh OJK paling lama 30 hari kerja sejak penandatanganan perjanjian fasilitasi, dan dapat diperpanjang sampai dengan 30 hari kerja berikutnya berdasarkan kesepakatan Konsumen dan Bank. Kesepakatan hasil dari proses fasilitasi oleh OJK dituangkan dalam akta kesepakatan yang ditandatangani Konsumen dan Bank. Menurut SEBI No.8 Tahun 2006 akta kesepakatan bersifat final dan mengikat, artinya sengketa yang telah diselesaikan tidak dapat diajukan untuk proses fasilitasi ulang di OJK dan berlaku sebagai undang-undang bagi Konsumen dan Bank. Pelanggaran atas pelaksanaan ketentuan dalam akta kesepakatan merupakan wanprestasi dan dapat dituntut melalui gugatan perdata. apabila tidak ada kesepakatan maka Konsumen dan Bank menandatangani berita acara hasil fasilitasi OJK dan Konsumen dapat mengajukan gugatan perdata ke pengadilan. 


\section{Penutup}

Pelaksanaan penyelesaian sengketa perbankan pasca keluarnya Undang-Undang OJK terjadi peralihan kewenangan terkait lembaga yang menjadi fasilitator mediasi perbankan dari BI ke OJK yang ditangani Bidang Edukasi dan Perlindungan Konsumen, Direktorat Pelayanan Konsumen. Untuk menjalankan kewenangan tersebut OJK mengeluarkan praturan-peraturan terkait yaitu POJK No.1/POJK.07/2013 tentang Perlindungan Konsumen Sektor Jasa Keuangan, POJK No.1/POJK.07/2014 tentang Lembaga Alternatif Penyelesaian Sengketa, dan SE OJK Nomor 2/SEOJK.07/2014 tentang Pelayanan dan Penyelesaian Pengaduan Konsumen Pada Pelaku Usaha Jasa Keuangan.

\section{DAFTAR PUSTAKA}

Anshori, Abdul Ghafur. 2007. Peradilan Agama di Indonesia Pasca Undang-Undang Nomor 3 Tahun 2006. Jakarta: UII Press.

Chatamarrasjid, Ais. 1999. Penyelesaian Konflik: Arbitrase dan Pengadilan. Jakarta: t.pn. 1999.

Moore, Christoper W. 1995. Mediasi Lingkungan. Jakarta: Indonesian Center for Environmental Law dan CDR Associete.

Goodpaster, Gary. 1993. Negosiasi dan Mediasi: Sebuah Pedoman Negosiasi dan Penyelesaian Sengketa Melalui Negosiasi. Jakarta: Elips Project.

Adolf, Huala. 1994. Hukum Arbitrase Komersil Internasional Jakarta: PT. RajaGrafindo Persada.

Adolf, Huala. 2004. Hukum Penyelesaian Sengketa Internasional. Jakarta: Sinar Gafika.

Kusumaatmadja, Mochtar. 2000. Pengantar Ilmu Hukum. Bandung: PT. Alumni.

Kusumaatmadja, Mochtar. 2006. Konsep-konsep Hukum dalam Pembangunan. Bandung: PT. Alumni.

Fuady, Munir. 2003. Arbitrase Nasional: Alternatif Penyelesaian, Sengketa Bisnis. Bandung: PT. Citra Aditya Bakti.

Umar, M. Husyein dan Kardono, A. Supriyani. 1995. Hukum dan Lembaga Arbitrase di Indonesia. Jakarta: Elips. 
Harahap, M. Yahya. 1989. Ruang Lingkup Permasalahan Eksekusi Bidang Perdata. Jakarta: PT. Gramedia.

Usman, Rachmadi. 2003. Pilihan Penyelesaian Sengketa di Luar Pengadilan. Bandung: PT. Citra Aditya Bhakti.

Margono, Suyud. 2004. ADR \& Arbitrase: Proses Pelembagaan dan Aspek Hukum. Bogor: Ghalia Indonesia.

Soekanto, Soerjono. 1986. Pengantar Penelitian Hukum. Jakarta: UIPress.

Undang-undang Nomor 7 Tahun 1992 tentang Perbankan.

Undang-undang Nomor 10 Tahun 1998 tentang Perubahan Atas Undang-undang Nomor 7 Tahun 1992 tentang Perbankan.

Undang-undang Nomor 21 Tahun 2008 tentang Perbankan Syariah.

Peraturan Bank Indonesia Nomor:7/7/PBI/2005 tentang Penyelesaian Pengaduan Nasabah.

Peraturan Bank Indonesia Nomor: 8/5/PBI/2006 tentang Mediasi Perbankan.

Peraturan Bank Indonesia Nomor: 10/1/PBI/2008 tentang Perubahan Atas Peraturan Bank Indonesia Nomor: 8/5/PBI/2006 tentang Mediasi Perbankan.

Peraturan OJK No. 1/POJK.07/2013 tentang Perlindungan Konsumen Sektor Jasa Keuangan.

Peraturan OJK No. 1/POJK.07/2014 tentang Lembaga Alternatif Penyelesaian Sengketa.

Surat Edaran OJK No. 2/SEOJK.07/2014 tanggal 14 Februari 2014 tentang Pelayanan dan Penyelesaian Pengaduan Konsumen Pada Pelaku Usaha Jasa Keuangan. 